\title{
Study to Explore Diverse Interactions by Physicochemical Contrivance of an Ionic Liquid in Aqueous Oligosaccharides
}

\author{
Biswajit Datta, Ananya Yasmin, Mahendra Nath Roy* \\ Department of Chemistry, University of North Bengal, Darjeeling - 734 013, West Bengal, India.
}

\section{ARTICLE DETAILS}

\section{Article history:}

Received 06 December 2017

Accepted 21 February 2018

Available online 09 March 2018

\section{Keywords:}

Green Solvent

Limiting Molal Conductivities

Potential Toxicity

\begin{abstract}
A B S T R A C T
In this article interaction properties of an IL, 1-butyl-1-methylpyrrolidinium chloride ([bmp]Cl) have been studied in different concentrations of aqueous $\mathrm{D}(-)$ fructose and $\mathrm{D}(+)$ galactose solutions at diverse temperatures. In spite of having "green solvent" property toxicity of ILs has been revealed. So the interface of ILs with biomolecules (such as carbohydrates) is a progressive research topic. The limiting molal conductivities, association constants of the ion have been evaluated. From density measurement the limiting apparent molal volumes, experimental slopes and the limiting partial molal transfer volumes, $\Delta_{t r} \phi_{v}^{0}$ are derived. Viscosity measurement helps to determine viscosity - $B$ coefficients and $\mathrm{dB} / \mathrm{dT}$. The association constant has been used to study the thermodynamic functions of association process. Consequently, Gibbs free energy $\left(\Delta G_{A}^{0}\right)$, enthalpy $\left(\Delta H_{A}^{0}\right)$ and entropy $\left(\Delta S_{A}^{0}\right)$ of ion-pair formation have been determined. In addition, the ${ }^{1} \mathrm{H}$ NMR spectra of carbohydrates, IL and carbohydrate $+\mathrm{IL}+\mathrm{D}_{2} \mathrm{O}$ were studied. The NMR study does not show any special and strong interactions between IL and carbohydrates but, the macro properties and their changes in terms of size and structure of carbohydrates and IL have been discussed. By means of the interaction between IL and biomolecules, the potential toxicity of ILs may originate.
\end{abstract}

\section{Introduction}

Ionic liquids (IL) have in recent times emerged as "green" and environment friendly solvents $[1,2]$ for their use in the industrial manufacture of chemicals. Ionic liquids have been increasingly used for diverse applications such as organic synthesis, catalysis, electrochemical devices and solvent extraction of a variety of compounds. Ionic liquids are composed of cations and anions having low melting points $\left(<100{ }^{\circ} \mathrm{C}\right)$. The interest in ionic liquids was initiated because of their advantageous physicochemical properties such as negligible vapour pressure, high thermal and electrochemical stability, high solvating power etc., [3-5]. Abundant current books, academic journal reviews and conference proceedings provide us an idea about the expansive band of research and latent manufacturing applications for ionic liquids. The important uses of [bmp]Cl are largely in catalysts, battery electrolytes, syntheses (excluding the catalysts group), and electrochemical relevancies other than batteries.

Living system of every animal and man is composed of several molecules having specific functions are termed as biomolecules. Carbohydrates are one of the main classes of biomolecules. Carbohydrates (such as glucose, fructose, galactose etc.) are most important substances to all living organisms. They usually act as a ubiquitous fuel for biological processes to supply necessary energy for the function of the living and their day's work. Taken carbohydrates $\mathrm{D}(+)$ galactose and $\mathrm{D}(-)$ fructose are very significant variety of saccharide. An unusual level of carbohydrate in human body fluid is a caution hint of a medical stipulation. such as, an unbalanced concentration of carbohydrates in human blood or urine entails a biological dysfunction.

In spite of the "green" aspects of ILs, the potential toxicity of the ILs released into the environment cannot be overlooked [6]. Since ILs are highly stable in water, they may be a health hazard by gathering in the ecological atmosphere and organisms. So, it is very important to determine the potential toxicity of ILS originate from the interface between ILs and biomolecules. Thus it is a progressive research topic to investigate the interactions between ILs and biomolecules such as carbohydrates.
In this present case, an attempt has been made to reveal the nature of various types of interactions prevailing an ionic liquid in aqueous carbohydrates [D(-)fructose and $\mathrm{D}(+)$ galactose] solutions from conductometric, volumetric, viscometric and NMR measurements. Aim of the present work is to study the molecular interactions of IL in aqueous solutions of carbohydrates by physicochemical and thermodynamical studies, and the structural effect of carbohydrates as literature survey reveals that very ample work has been carried out in the present ternary systems especially given that theoretical foundations and significant information for studies on the potential toxicity of ILs. Such study helps in better understanding of the interactions occurring between carbohydrate molecules and entities present in mixed aqueous medium in the living cells through thermodynamics and transport properties. All of the derived parameters have been discussed in term of interactions between ionic liquid and carbohydrates.

\section{Experimental Methods}

\subsection{Source and Purity of Samples}

The chosen IL for this current work purist grade was procured from Sigma-Aldrich, Germany and was used as purchased. The mass fraction purity of the IL, 1-butyl-1-methylpyrrolidinium chloride ([bmp]Cl) was $\geq$ 99\%. D(-)fructose and D(+)galactose were procured from Thomas Baker, Mumbai. The mass fraction purity of $\mathrm{D}(-)$ fructose and $\mathrm{D}(+)$ galactose was $\geq$ 99.4\% and $99.9 \%$ respectively. IL, D(-)fructose and $\mathrm{D}(+)$ galactose were dried in vacuum desiccator over $\mathrm{P}_{2} \mathrm{O}_{5}$ at room temperature for at least $72 \mathrm{~h}$.

\subsection{Apparatus and Procedure}

All the stock solutions of $\mathrm{D}(-)$ fructose, $\mathrm{D}(+)$ galactose and the electrolyte (IL) were prepared by mass (weighed by Mettler Toledo AG-285 with uncertainty $0.0003 \mathrm{~g}$ ). For conductance the working solutions, were obtained by mass dilution of the stock solutions [7-9].

The conductance measurements were carried out in a Systronics-308 conductivity bridge of accuracy $\pm 0.01 \%$, using a dip-type immersion conductivity cell, CD-10 having a cell constant of approximately $(0.1 \pm 0.001) \mathrm{cm}^{-1}$. Measurements were made in a thermostat water bath maintained at $\mathrm{T}=(298.15 \pm 0.01) \mathrm{K}$. The cell was calibrated by the method 
proposed by Lind et al. and cell constant was measured based on $0.01 \mathrm{M}$ aqueous $\mathrm{KCl}$ solution. During the conductance measurements, cell constant was maintained within the range $1.10-1.12 \mathrm{~cm}^{-1}$. The conductance data were reported at a frequency of $1 \mathrm{kHz}$ and the accuracy was $\pm 0.3 \%$. During all the measurements, uncertainty of temperatures was $\pm 0.01 \mathrm{~K}$.

The densities of the solvents and experimental solutions $(\boldsymbol{\rho})$ were measured by means of vibrating u-tube Anton Paar digital density meter (DMA $4500 \mathrm{M}$ ) with a precision of $\pm 0.00005 \mathrm{~g} \mathrm{~cm}^{-3}$ maintained at $\pm 0.01 \mathrm{~K}$ of the desired temperature. It was calibrated by triply-distilled water and passing dry air.

The viscosities were measured using a Brookfield DV-III Ultra Programmable Rheometer with fitted spindle size-42 fitted to a Brookfield digital bath TC-500. The viscosities were obtained using the following equation, $\eta=(100 / \mathrm{RPM}) \times \mathrm{TK} \times$ torque $\times \mathrm{SMC}$, where $R P M, T K(0.09373)$ and $S M C(0.327)$ are the speed, viscometer torque constant and spindle multiplier constant, respectively. The instrument was calibrated against the standard viscosity samples supplied with the instrument, water and aqueous $\mathrm{CaCl}_{2}$ solutions. Temperature of the solution was maintained to within $\pm 0.01 \mathrm{~K}$ using Brookfield Digital TC-500 temperature thermostat bath. The viscosities were measured with an accuracy of $\pm 1 \%$.

Each measurement reported herein is an average of triplicate reading with a precision of $0.3 \%$. NMR spectra were recorded in $\mathrm{D}_{2} \mathrm{O}$ at 400 $\mathrm{MHz}$ using Bruker ADVANCE $400 \mathrm{MHz}$ instrument at 298.15 K. Signals are cited as $\delta$ values in ppm using residual protonated solvent signals as internal standard (D20 : $\delta 4.79 \mathrm{ppm}$ ). Data are reported as chemical shift.

\section{Results and Discussion}

In the beginning it may be point out that there is no difference between $\mathrm{D}(+)$ and $\mathrm{D}(-)$ form of galactose and fructose in their physical properties in our experimental works. Fructose, or fruit sugar, is a simple ketonic monosaccharide found in many plants and Galactose exists in both open-chain and cyclic form. The open-chain form has a carbonyl at the end of the chain. Four isomers are cyclic, two of them with a pyranose (six-membered) ring anf another two isomers are with a furanose (five-membered) ring. Galactofuranose mostly occurs in bacteria, fungi and protozoa. In our experiment we have taken $\alpha$-form of $\mathrm{D}(-)$ fructose and on the other hand $\mathrm{D}(+)$ Galactose taken in the experiment is in the form of $20 \%$ of $\alpha$ - and $80 \%$ of $\beta$-form. The solvent properties are given in Table 1.

Table 1 Density $(\rho)$, viscosity $(\eta)$ and relative permittivity $(\varepsilon)$ of the different concentration $(\mathrm{m})$ of aqueous D(-)fructose and D(+)galactose at 298.15, 303.15 and $308.15 \mathrm{~K}^{a}$ respectively

\begin{tabular}{|c|c|c|c|}
\hline $\mathrm{T}(\mathrm{K})$ & $\rho \cdot 10^{-3} / \mathrm{kg} \mathrm{m}^{-3}$ & $\eta / \mathrm{mPa} \mathrm{s}$ & $\varepsilon$ \\
\hline \multicolumn{4}{|c|}{$\mathrm{m}_{\mathrm{D}(- \text {-)fructose }}=0.2 \mathrm{~mol} \mathrm{~kg}^{-1}$} \\
\hline 298.15 & 1.0039 & 0.93 & 78.1 \\
\hline 303.15 & 1.0025 & 0.91 & 76.3 \\
\hline 308.15 & 1.0018 & 0.89 & 74.5 \\
\hline \multicolumn{4}{|c|}{$\mathrm{mD}_{\mathrm{D}-\text {-)fructose }}=0.4 \mathrm{~mol} \mathrm{~kg}^{-1}$} \\
\hline 298.15 & 1.0051 & 0.93 & 77.4 \\
\hline 303.15 & 1.0028 & 0.91 & 75.5 \\
\hline 308.15 & 1.0021 & 0.90 & 73.8 \\
\hline \multicolumn{4}{|c|}{$\mathrm{m}_{\mathrm{D}(-) \text { fructose }}=0.6 \mathrm{~mol} \mathrm{~kg}^{-1}$} \\
\hline 298.15 & 1.0062 & 0.93 & 76.8 \\
\hline 303.15 & 1.0049 & 0.92 & 74.9 \\
\hline 308.15 & 1.0027 & 0.90 & 73.1 \\
\hline \multicolumn{4}{|c|}{$\mathrm{mD}(+)$ galactose $=0.2 \mathrm{~mol} \mathrm{~kg}^{-1}$} \\
\hline 298.15 & 1.0037 & 0.93 & 78.1 \\
\hline 303.15 & 1.0023 & 0.91 & 76.3 \\
\hline 308.15 & 1.0015 & 0.90 & 74.5 \\
\hline \multicolumn{4}{|c|}{$\mathrm{m}_{\mathrm{D}(+) \text { galactose }}=0.4 \mathrm{~mol} \mathrm{~kg}^{-1}$} \\
\hline 298.15 & 1.0045 & 0.93 & 77.4 \\
\hline 303.15 & 1.0025 & 0.92 & 75.5 \\
\hline 308.15 & 1.0020 & 0.90 & 73.8 \\
\hline \multicolumn{4}{|c|}{$\mathrm{m}_{\mathrm{D}(+) \text { galactose }}=0.6 \mathrm{~mol} \mathrm{~kg}-1$} \\
\hline 298.15 & 1.0059 & 0.93 & 76.8 \\
\hline 303.15 & 1.0047 & 0.92 & 74.9 \\
\hline 308.15 & 1.0025 & 0.90 & 73.1 \\
\hline
\end{tabular}

a Standard uncertainties $u$ are: $u(\rho)= \pm 5 \times 10^{-5} \mathrm{gcm}^{-3}, u(\eta)= \pm 1 \%$ and $u(T)= \pm 0.01 \mathrm{~K}$

Conductivity measurements have been carried out to obtain information on association behaviour and ion-solvent interactions $[10,11]$ of the ionic liquid, [bmp]Cl, in $(0.2,0.4$ and 0.6$) \mathrm{molkg}^{-1}$ aqueous $\mathrm{D}(-)$ fructose and $\mathrm{D}(+)$ galactose solutions at temperatures ranging from
(298.15-308.15) K. The concentrations and molar conductances $(\Lambda)$ of IL in aqueous solution of $\mathrm{D}(-)$ fructose and $\mathrm{D}(+)$ galactose at different temperatures are given in Table 2 . The molar conductance $(\Lambda)$ has been obtained from the specific conductance $(\kappa)$ value using the following equation,

$$
\Lambda=(1000 \kappa) / \mathrm{m}
$$

Linear conductance curves $(\Lambda$ versus $\sqrt{\mathrm{m}})$ were obtained for the electrolyte in aq. solution of D(-)fructose. D(+) Galactose, extrapolation of $\sqrt{\mathrm{m}}=0$ evaluated the starting limiting molar conductance for the electrolyte. The values of $\mathrm{K}_{\mathrm{A}}, \Lambda_{0}$ and $\mathrm{R}$ obtained by this procedure are given in Table 3

Table 2 Molar conductivities $(\Lambda)$ of [bmp]Cl in aqueous $\mathrm{D}(-)$ fructose solutions as a function of ionic liquid molality $(\mathrm{m})$ at different temperatures

\begin{tabular}{|c|c|c|c|c|c|}
\hline $\begin{array}{l}c \cdot 10^{4} / \\
\mathrm{mol} \cdot \mathrm{dm}^{-3}\end{array}$ & $\begin{array}{l}\Lambda \cdot 10^{4} / \\
\mathrm{S} \cdot \mathrm{m}^{2} \cdot \mathrm{mol}^{-1}\end{array}$ & $\begin{array}{l}c \cdot 10^{4} / \\
\mathrm{mol} \cdot \mathrm{dm}^{-3}\end{array}$ & $\begin{array}{l}\Lambda \cdot 10^{4} / \\
\mathrm{S} \cdot \mathrm{m}^{2} \cdot \mathrm{mol}^{-1}\end{array}$ & $\begin{array}{l}c \cdot 10^{4} / \\
\mathrm{mol} \cdot \mathrm{dm}^{-3}\end{array}$ & $\begin{array}{l}\Lambda \cdot 10^{4} / \\
\mathrm{s} \cdot \mathrm{m}^{2} \cdot \mathrm{mol}^{-1}\end{array}$ \\
\hline $\mathrm{T}=298.15 \mathrm{~K}$ & & $\mathrm{~T}=303.15$ & & $\mathrm{~T}=308.15 \mathrm{~K}$ & \\
\hline \multicolumn{6}{|c|}{$\mathrm{m}_{\mathrm{D}(-) \text { fructose }}=0.2 \mathrm{~mol} \mathrm{~kg}^{-1}$} \\
\hline 0.0114 & 101.10 & 0.0122 & 104.58 & 0.0132 & 107.60 \\
\hline 0.0173 & 99.13 & 0.0223 & 101.91 & 0.0251 & 104.57 \\
\hline 0.0239 & 96.45 & 0.0309 & 99.93 & 0.0320 & 103.13 \\
\hline 0.0296 & 94.32 & 0.0383 & 98.20 & 0.0398 & 101.50 \\
\hline 0.0345 & 92.40 & 0.0447 & 96.79 & 0.0469 & 99.90 \\
\hline 0.0389 & 91.01 & 0.0503 & 95.34 & 0.0523 & 97.40 \\
\hline 0.0427 & 89.91 & 0.0552 & 94.33 & 0.0579 & 96.80 \\
\hline 0.0464 & 88.51 & 0.0596 & 93.18 & 0.0613 & 95.00 \\
\hline 0.0512 & 87.91 & 0.0635 & 92.21 & 0.0647 & 94.26 \\
\hline 0.0551 & 86.94 & 0.0670 & 91.44 & 0.0684 & 93.89 \\
\hline 0.0593 & 85.50 & 0.0702 & 90.53 & 0.0715 & 92.03 \\
\hline 0.0672 & 84.29 & 0.0731 & 89.91 & 0.0750 & 91.59 \\
\hline 0.0715 & 83.11 & 0.0757 & 89.12 & 0.0765 & 90.53 \\
\hline 0.0763 & 81.82 & 0.0782 & 88.09 & 0.0792 & 89.05 \\
\hline 0.0841 & 80.20 & 0.0804 & 87.58 & 0.0815 & 89.78 \\
\hline \multicolumn{6}{|c|}{$\mathrm{m}_{\mathrm{D}(-) \text { fructose }}=0.4 \mathrm{~mol} \mathrm{~kg}^{-1}$} \\
\hline 0.0121 & 99.43 & 0.0138 & 102.37 & 0.0142 & 105.85 \\
\hline 0.0187 & 97.40 & 0.0235 & 100.75 & 0.0216 & 104.70 \\
\hline 0.0241 & 95.04 & 0.0313 & 99.55 & 0.0285 & 103.58 \\
\hline 0.0310 & 93.62 & 0.0385 & 97.16 & 0.0346 & 102.62 \\
\hline 0.0353 & 92.56 & 0.0465 & 95.91 & 0.0388 & 101.66 \\
\hline 0.0395 & 90.90 & 0.0513 & 94.12 & 0.0438 & 100.70 \\
\hline 0.0443 & 90.42 & 0.0544 & 93.40 & 0.0491 & 99.67 \\
\hline 0.0475 & 88.35 & 0.0596 & 93.95 & 0.0551 & 97.57 \\
\hline 0.0496 & 87.45 & 0.0635 & 92.88 & 0.0617 & 95.46 \\
\hline 0.0542 & 85.76 & 0.0674 & 90.18 & 0.0675 & 93.24 \\
\hline 0.0595 & 84.67 & 0.0715 & 89.52 & 0.0707 & 91.72 \\
\hline 0.0657 & 83.63 & 0.0742 & 88.87 & 0.0731 & 89.29 \\
\hline 0.0713 & 82.73 & 0.0774 & 88.09 & 0.0779 & 89.84 \\
\hline 0.0765 & 81.62 & 0.0812 & 87.48 & 0.0821 & 88.79 \\
\hline 0.0846 & 79.38 & 0.0851 & 86.83 & 0.0852 & 88.30 \\
\hline \multicolumn{6}{|c|}{$\mathrm{m}_{\mathrm{D}(-) \text { fructose }}=0.6 \mathrm{~mol} \mathrm{~kg}^{-1}$} \\
\hline 0.0128 & 95.51 & 0.0143 & 98.99 & 0.0152 & 102.57 \\
\hline 0.0185 & 94.48 & 0.0242 & 97.04 & 0.0271 & 100.17 \\
\hline 0.0229 & 93.20 & 0.0316 & 95.70 & 0.0331 & 99.03 \\
\hline 0.0282 & 91.54 & 0.0386 & 94.52 & 0.0423 & 97.20 \\
\hline 0.0313 & 90.40 & 0.0451 & 93.13 & 0.0481 & 96.00 \\
\hline 0.0351 & 89.27 & 0.0503 & 92.03 & 0.0542 & 94.75 \\
\hline 0.0420 & 87.31 & 0.0557 & 91.06 & 0.0598 & 93.33 \\
\hline 0.0456 & 86.00 & 0.0596 & 90.21 & 0.0631 & 92.92 \\
\hline 0.0494 & 85.65 & 0.0635 & 89.45 & 0.0656 & 92.24 \\
\hline 0.0499 & 84.91 & 0.0674 & 88.51 & 0.0699 & 90.17 \\
\hline 0.0540 & 83.18 & 0.0730 & 87.35 & 0.0731 & 89.54 \\
\hline 0.0591 & 82.23 & 0.0756 & 86.55 & 0.0763 & 88.91 \\
\hline 0.0664 & 81.26 & 0.0785 & 86.05 & 0.0782 & 88.15 \\
\hline 0.0719 & 80.09 & 0.0820 & 85.17 & 0.0819 & 87.99 \\
\hline 0.0786 & 78.08 & 0.0841 & 84.73 & 0.0860 & 87.57 \\
\hline
\end{tabular}

\subsection{Ion-Pair Formation}

The conductivity data of taken IL in aqueous solution of $D(-)$ fructose and $\mathrm{D}(+)$ galactose at different temperatures were analyzed using the Fuoss conductance equation [12]. With a given set of conductivity values $\left(\mathrm{m}_{j}, \Lambda_{j} ; j=1 \ldots \ldots . \mathrm{n}\right)$, three adjustable parameters, i.e., $\Lambda_{0}, K_{\mathrm{A}}$ and $R$ have been derived from the Fuoss equation. Here, $\Lambda_{0}$ is the limiting molar conductance, $K_{\mathrm{A}}$ is the observed association constant and $R$ is the association distance, i.e., the maximum centre to centre distance between the ions in the solvent separated ion-pairs. There is no precise method [13] 
for determining the $R$ value but in order to treat the data in our system, $R$ value is assumed to be, $R=a+d$, where $a$ is the sum of the crystallographic radii of the ions and $d$ is the average distance corresponding to the side of a cell occupied by a solvent molecule. The distance, $d$ is given by [14],

$$
d=1.183(M / \rho)^{l / 3}
$$

where, $M$ is the molecular mass and $\rho$ is the density of the solvent.

Thus, the Fuoss conductance equation may be represented as follows:

$$
\begin{aligned}
\Lambda & =P \Lambda_{o}\left[\left(1+R_{X}\right)+E_{L}\right] \\
P & =1-\alpha(1-\gamma) \\
\gamma & =1-K_{A} m \gamma^{2} f^{2} \\
-\ln f & =\beta \kappa / 2(1+\kappa R) \\
\beta & =e^{2} /\left(\varepsilon_{r} k_{B} T\right) \\
K_{A} & =K_{R} /(1-\alpha)=K_{R} /\left(1+K_{S}\right)
\end{aligned}
$$

where, $\Lambda_{0}$ is the limiting molar conductance, $K_{\mathrm{A}}$ is the observed association constant, $R$ is the association distance, $R$ x is the relaxation field effect, $E_{\mathrm{L}}$ is the electrophoretic counter current, $k$ is the radius of the ion atmosphere, $\varepsilon$ is the relative permittivity of the solvent mixture, $e$ is the electron charge, $c$ is the molarity of the solution, $k_{\mathrm{B}}$ is the Boltzmann constant, $K_{\mathrm{S}}$ is the association constant of the contact-pairs, $K_{\mathrm{R}}$ is the association constant of the solvent-separated pairs, $\gamma$ is the fraction of solute present as unpaired ion, $\alpha$ is the fraction of contact pairs, $f$ is the activity coefficient, $T$ is the absolute temperature and $\beta$ is twice the Bjerrum distance.

The computations were performed using the program suggested by Fuoss. The initial $\Lambda_{0}$ values for the iteration procedure are obtained from Shedlovsky extrapolation of the data [15]. Input for the program is the no. of data, $n$, followed by $\varepsilon, \eta$ (viscosity of the solvent mixture), initial $\Lambda_{0}$ value, $T, \rho$ (density of the solvent mixture), mole fraction of the first component, molar masses, $M_{1}$ and $M_{2}$ along with $\mathrm{m}_{j}, \Lambda_{j}$ values where $j=1,2 \ldots \ldots$... and an instruction to cover preselected range of $R$ values.

In practice, calculations are performed by finding the values of $\Lambda_{0}$ and $\alpha$ which minimize the standard deviation, $\delta$, whereby

$$
\delta^{2}=\sum\left[\Lambda_{j}(c a l)-\Lambda_{j}(o b s)\right]^{2} /(n-m)
$$

for a sequence of $R$ values and then plotting $\delta$ against $R$, the best- fit $R$ corresponds to the minimum of the $\delta$ - $R$ versus $R$ curve. So, an approximate sum is made over a fairly wide range of $R$ values using 0.1 increment to locate the minimum but no significant minima is found in the $\delta$ - $R$ curves, thus $R$ values is assumed to be $R=a+d$, with terms having usual significance. Finally, the corresponding limiting molal conductance $\left(\Lambda_{0}\right)$, association constant $\left(K_{\mathrm{A}}\right)$, co-sphere diameter $(R)$ and standard deviations of experimental $\Lambda(\delta)$ obtained from Fuoss conductance equation for $[\mathrm{bmp}] \mathrm{Cl}$ in aqueous solution of $\mathrm{D}(-)$ fructose and $\mathrm{D}(+)$ galactose at $298.15 \mathrm{~K}, 303.15 \mathrm{~K}$ and $308.15 \mathrm{~K}$ respectively are given in Table 3.

Table 3 Molar conductivities $(\Lambda)$ of $[\mathrm{bmp}] \mathrm{Cl}$ in aqueous $\mathrm{D}(+)$ galactose solutions as a function of ionic liquid molality $(\mathrm{m})$ at different temperatures

\begin{tabular}{|c|c|c|c|c|c|}
\hline $\mathrm{T}(\mathrm{K})$ & $\begin{array}{l}\mathrm{K}_{\mathrm{A}}\left(\mathrm{dm}^{3}\right. \\
\left.\mathrm{mol}^{-1}\right)\end{array}$ & $\Lambda_{\mathrm{o}}\left(\mathrm{S} \mathrm{cm}^{2} \mathrm{~mol}^{-1}\right)$ & $10^{10} \mathrm{R}(\mathrm{m})$ & $\Lambda_{0} \cdot \eta\left(\mathrm{S} \mathrm{cm}^{2} \mathrm{mPa} \mathrm{s} \mathrm{mol}^{-1}\right)$ & $\delta$ \\
\hline \multicolumn{6}{|c|}{$\mathrm{m}_{\mathrm{D}(-) \text { fructose }}=0.2 \mathrm{~mol} \mathrm{~kg}^{-1}$} \\
\hline 298.15 & 52.18 & 107.16 & 9.53 & 99.66 & 1.165 \\
\hline 303.15 & 51.78 & 110.11 & 9.59 & 100.20 & 0.729 \\
\hline 308.15 & 50.21 & 114.22 & 9.65 & 101.66 & 0.572 \\
\hline \multicolumn{6}{|c|}{$\mathrm{m}_{\mathrm{D}(-) \text { fructose }}=0.4 \mathrm{~mol} \mathrm{~kg}^{-1}$} \\
\hline 298.15 & 54.21 & 100.79 & 9.52 & 93.73 & 1.478 \\
\hline 303.15 & 52.91 & 105.10 & 9.55 & 95.64 & 1.261 \\
\hline 308.15 & 51.12 & 108.26 & 9.58 & 97.43 & 1.173 \\
\hline \multicolumn{6}{|c|}{$\overline{\mathrm{mD}_{\mathrm{D}-\text {-)fructose }}=0.6 \mathrm{~mol} \mathrm{~kg}^{-1}}$} \\
\hline 298.15 & 56.23 & 99.41 & 9.45 & 92.45 & 1.659 \\
\hline 303.15 & 55.29 & 103.39 & 9.49 & 95.12 & 1.392 \\
\hline 308.15 & 52.98 & 107.93 & 9.54 & 97.43 & 1.281 \\
\hline \multicolumn{6}{|c|}{$\mathrm{m}_{\mathrm{D}(+) \text { galactose }}=0.2 \mathrm{~mol} \mathrm{~kg}^{-1}$} \\
\hline 298.15 & 50.24 & 108.35 & 9.61 & 100.77 & 1.086 \\
\hline 303.15 & 48.36 & 111.27 & 9.63 & 101.26 & 0.695 \\
\hline 308.15 & 46.91 & 115.92 & 9.66 & 104.33 & 0.425 \\
\hline \multicolumn{6}{|c|}{$\mathrm{m}_{\mathrm{D}(+) \text { galactose }}=0.4 \mathrm{~mol} \mathrm{~kg}^{-1}$} \\
\hline 298.15 & 51.22 & 105.54 & 9.56 & 98.15 & 1.321 \\
\hline 303.15 & 50.53 & 107.03 & 9.60 & 98.47 & 1.053 \\
\hline 308.15 & 49.62 & 113.25 & 9.62 & 101.93 & 0.915 \\
\hline \multicolumn{6}{|c|}{$\mathrm{m}_{\mathrm{D}(+) \text { galactose }}=0.6 \mathrm{~mol} \mathrm{~kg}^{-1}$} \\
\hline 298.15 & 50.45 & 104.18 & 9.50 & 96.89 & 1.114 \\
\hline 303.15 & 49.28 & 106.34 & 9.57 & 97.83 & 0.992 \\
\hline 308.15 & 48.38 & 111.05 & 9.69 & 99.95 & 0.711 \\
\hline
\end{tabular}

\begin{tabular}{llllll}
\hline$c \cdot 10^{4} /$ & $\Lambda \cdot 10^{4} /$ & $c \cdot 10^{4} /$ & $\Lambda \cdot 10^{4} /$ & $c \cdot 10^{4} /$ & $\Lambda \cdot 10^{4} /$ \\
$\mathrm{mol} \cdot \mathrm{dm}^{-3}$ & $\mathrm{~S} \cdot \mathrm{m}^{2} \cdot \mathrm{mol}^{-1}$ & $\mathrm{~mol} \cdot \mathrm{dm}^{-3}$ & $\mathrm{~S} \cdot \mathrm{m}^{2} \cdot \mathrm{mol}^{-1}$ & $\mathrm{~mol} \cdot \mathrm{dm}^{-3}$ & $\mathrm{~S} \cdot \mathrm{m}^{2} \cdot \mathrm{mol}^{-1}$ \\
\hline $\mathrm{T}=298.15 \mathrm{~K}$ & $\mathrm{~T}=303.15$ & & $\mathrm{~T}=308.15 \mathrm{~K}$ & \\
\hline $\mathrm{m}_{\mathrm{D}(+ \text { )galactose }}=0.2 \mathrm{~mol} \mathrm{~kg}^{-1}$ & & & & \\
\hline 0.0118 & 102.50 & 0.0142 & 105.13 & 0.0129 & 108.95 \\
0.0233 & 99.52 & 0.0254 & 102.86 & 0.0241 & 106.07 \\
0.0311 & 97.58 & 0.0330 & 100.97 & 0.0303 & 105.43 \\
0.0381 & 96.24 & 0.0396 & 99.54 & 0.0380 & 104.35 \\
0.0445 & 94.71 & 0.0482 & 98.65 & 0.0449 & 102.63 \\
0.0525 & 93.12 & 0.0521 & 97.54 & 0.0515 & 101.80 \\
0.0558 & 92.12 & 0.0582 & 96.40 & 0.0560 & 100.96 \\
0.0594 & 91.65 & 0.0616 & 95.20 & 0.0602 & 99.94 \\
0.0638 & 90.48 & 0.0650 & 94.48 & 0.0629 & 99.06 \\
0.0674 & 89.24 & 0.0687 & 93.74 & 0.0662 & 98.99 \\
0.0715 & 88.10 & 0.0726 & 92.03 & 0.0707 & 98.76 \\
0.0740 & 87.19 & 0.0752 & 91.84 & 0.0732 & 97.09 \\
0.0774 & 85.91 & 0.0765 & 91.23 & 0.0749 & 96.82 \\
0.0787 & 85.22 & 0.0792 & 91.95 & 0.0782 & 95.50 \\
0.0815 & 84.76 & 0.0815 & 90.40 & 0.0821 & 94.60 \\
\hline $\mathrm{m}_{\mathrm{D}(+) \text { galactose }}=0.4 \mathrm{~mol} \mathrm{~kg}-1$ & & & & \\
\hline 0.0124 & 100.33 & 0.0129 & 103.49 & 0.0142 & 107.87 \\
0.0173 & 98.93 & 0.0196 & 102.40 & 0.0265 & 105.27 \\
0.0249 & 97.37 & 0.0279 & 101.12 & 0.0325 & 104.03 \\
0.0311 & 95.32 & 0.0352 & 99.76 & 0.0409 & 102.22 \\
0.0355 & 94.46 & 0.0418 & 98.68 & 0.0464 & 101.11 \\
$\mathrm{https} / /$ doi.org $/ 10.30799 / \mathrm{jacs} .173 .18040103$ & & & \\
& & & & & \\
\hline
\end{tabular}

\begin{tabular}{llllll}
\hline 0.0395 & 92.60 & 0.0472 & 97.80 & 0.0531 & 99.60 \\
0.0443 & 91.50 & 0.0518 & 96.92 & 0.0567 & 98.89 \\
0.0475 & 90.50 & 0.0562 & 95.40 & 0.0604 & 98.06 \\
0.0496 & 90.06 & 0.0609 & 94.53 & 0.0654 & 96.85 \\
0.0542 & 89.86 & 0.0670 & 93.51 & 0.0698 & 95.93 \\
0.0599 & 88.77 & 0.0705 & 92.92 & 0.0727 & 95.20 \\
0.0657 & 86.43 & 0.0736 & 91.25 & 0.0758 & 94.63 \\
0.0721 & 85.63 & 0.0770 & 90.55 & 0.0784 & 94.24 \\
0.0765 & 85.04 & 0.0807 & 89.01 & 0.0821 & 93.60 \\
0.0844 & 83.30 & 0.0845 & 89.33 & 0.0880 & 92.13 \\
\hline $\mathrm{m} \mathrm{D}+$ galactose & $0.6 \mathrm{~mol} \mathrm{~kg}^{-1}$ & & & & \\
\hline 0.0153 & 97.11 & 0.0140 & 101.41 & 0.0150 & 105.25 \\
0.0253 & 94.91 & 0.0215 & 99.83 & 0.0259 & 102.97 \\
0.0331 & 92.80 & 0.0316 & 97.63 & 0.0329 & 101.53 \\
0.0423 & 91.75 & 0.0371 & 96.60 & 0.0384 & 100.41 \\
0.0481 & 90.28 & 0.0429 & 95.64 & 0.0430 & 99.19 \\
0.0542 & 89.07 & 0.0494 & 94.32 & 0.0487 & 97.94 \\
0.0598 & 88.11 & 0.0530 & 93.37 & 0.0527 & 97.11 \\
0.0631 & 87.23 & 0.0583 & 92.44 & 0.0581 & 96.00 \\
0.0656 & 86.21 & 0.0629 & 91.49 & 0.0624 & 95.17 \\
0.0699 & 85.23 & 0.0652 & 91.03 & 0.0667 & 94.22 \\
0.0731 & 84.16 & 0.0714 & 89.65 & 0.0715 & 92.95 \\
0.0763 & 83.03 & 0.0744 & 88.93 & 0.0758 & 92.11 \\
0.0782 & 81.93 & 0.0775 & 88.15 & 0.0785 & 91.67 \\
0.0819 & 80.99 & 0.0812 & 87.71 & 0.0823 & 90.72 \\
0.0862 & 80.33 & 0.0854 & 86.82 & 0.0859 & 90.08 \\
\hline & & & & &
\end{tabular}

Table 4 Ion association constants $\left(\mathrm{K}_{\mathrm{A}}\right)$, limiting molar conductivities $\left(\Lambda_{0}\right)$, distance parameters (R), Walden product $\left(\Lambda_{0} \cdot \eta\right)$ and and standard deviations of experimental $\Lambda(\delta)$ obtained from Fuoss conductance equation of IL in aqueous $\mathrm{D}(-)$ fructose and $\mathrm{D}(+)$ galactose solutions as a function of ionic liquid molality $(\mathrm{m})$ at different temperatures

\subsection{Limiting Molal Conductivities}

Assessment of Table 2 and Table 3 allocate that the $\Lambda_{0}$ values of the ionic liquid decrease with increasing the concentration of $D(-)$ fructose and $\mathrm{D}(+)$ galactose. This can be ascribed to the facts that with increase in $\mathrm{D}(-)$ fructose and $\mathrm{D}(+)$ galactose concentration (i) the microscopic viscosity of the mixtures increases thereby the mobility of ions decreases, and (ii) the solvated radii of ions become larger through an enhancement in the interactions between ionic liquid and $D(-)$ fructose and $\mathrm{D}(+)$ galactose solution therefore, the mobility of ions decreases [16]. On the other hand, the $\Lambda_{0}$ values increase from $D(-)$ fructose to $D(+)$ galactose. Due to higher viscosity value of $D(-)$ fructose than $\mathrm{D}(+)$ galactose $\Lambda_{0}$ values increase in $\mathrm{D}(+)$ galactose than in $\mathrm{D}(-)$ fructose. $\Lambda_{0}$ values increase in every solution with increase of temperature. With increasing temperature mobility of the concerned ions in solution increases, so $\Lambda_{0}$ values increase.

\subsection{Thermodynamic of the Ion-Association Process}

Values of the association constant $\left(\mathrm{K}_{\mathrm{A}}\right)$ for the ionic liquids in aqueous $\mathrm{D}(-)$ fructose and $\mathrm{D}(+)$ galactose solutions are shown in Table 
4. It is obvious that at a fixed concentration of $D(-)$ fructose and $\mathrm{D}(+)$ galactose, the $\mathrm{K}_{\mathrm{A}}$ values decrease from $\mathrm{D}(-)$ fructose to $\mathrm{D}(+)$ galactose and also decrease with increasing temperature in each solution. The association constant $\left(\mathrm{K}_{\mathrm{A}}\right)$ for the ionic association reaction can serve to study the thermodynamic of this process. Consequently, the standard Gibbs energy $\left(\mathrm{G}_{A}{ }^{0}\right)$ for the ion-association process were calculated according to the following equation [17]

$$
\Delta G_{A}^{o}=-R T \ln K_{A}
$$

The obtained values of the standard Gibbs energy are collected in Table 6. Table 6 indicates that the ion-association process exhibits a negative value of $\left(\mathrm{G}_{A}{ }^{0}\right)$ and becomes more negative in $\mathrm{D}(+)$ galactose than in $\mathrm{D}(-)$ fructose. This indicates that ion-association process is more feasible in $\mathrm{D}(+)$ galactose solution. Walden product value (Table 6) shows that ionic mobility is higher in case of $\mathrm{D}(+)$ galactose solution than in $\mathrm{D}(-)$ fructose solution and ionic mobility increases with increasing temperature.

Temperature-dependent of $\mathrm{G}_{\mathrm{A}}{ }^{0}$ was expressed with the help of a polynomial [18]

$\Delta G_{A}^{o}(T)=A_{o}+A_{t}(298.15-T)+A_{2}(298.15-T)^{2}$

Entropy and enthalpy of ion association have been obtained as follows

$$
\begin{aligned}
& \Delta \mathrm{S}_{A}^{0}(\mathrm{~T})=-\left(\frac{\partial \Delta G_{A}^{0}(T)}{\partial T}\right)_{P}=A_{1}+2 A_{2}(298.15-T) \\
& \Delta \mathrm{H}_{A}^{0}(\mathrm{~T})=\Delta G_{A}^{0}(\mathrm{~T})+\mathrm{T} \Delta \mathrm{S}_{A}^{0}(\mathrm{~T})=A_{0}+298.15 A_{1}+\left(298.15^{2}-T^{2}\right) A_{2}
\end{aligned}
$$

The values of the coefficients $A_{0}, A_{1}$ and $A_{2}$ at different solvent compositions are given in Table 5. The calculated thermodynamic functions of IL in $\mathrm{D}(-)$ fructose and $\mathrm{D}(+)$ galactose solutions are listed in Table 6 and are represented graphically by Figs. 1-3 respectively. Table 6 indicates that the ion-association process exhibits a negative value of $\Delta \mathrm{G}_{\mathrm{A}}{ }^{0}$ and becomes more negative with increasing temperature proposing the spontaneity and feasibility of the association process at high temperatures. In all cases, the $\Delta \mathrm{S}_{A}{ }^{0}$ values are positive over the whole temperature range. The positive $\Delta \mathrm{S}_{\mathrm{A}}{ }^{0}$ values may be attributed to the increasing number of degrees of freedom due to the release of solvent molecules from hydration shells as the association takes place. In other words, the solvation of the individual ions is weakened as soon as these ion-pairs are formed.

Table 5 The values of coefficients in Eq. (11) $A_{0}, A_{1}$ and $A_{2}$ at different solvent compositions

\begin{tabular}{llll}
\hline Conc. $(\mathrm{M})$ & $\mathrm{A}_{0.10^{-6}}\left(\mathrm{~J} \mathrm{~mol}^{-1}\right)$ & $\mathrm{A}_{1}\left(\mathrm{KJ} \mathrm{mol}^{-1} \mathrm{~K}^{-1}\right)$ & $\mathrm{A}_{2}\left(\mathrm{~J} \mathrm{~mol}^{-1} \mathrm{~K}^{-2}\right)$ \\
\hline $\mathrm{D}(-)$ fructose & & & \\
\hline 0.2 & -2.18 & 11.31 & -18.82 \\
0.4 & -1.46 & 10.91 & -18.15 \\
0.6 & -1.14 & 9.97 & -16.60 \\
\hline $\mathrm{D}(-)$ galactose & & & \\
\hline 0.2 & -2.02 & 10.28 & -17.08 \\
0.4 & -1.35 & 8.49 & -14.12 \\
0.6 & -1.05 & 8.09 & -13.47 \\
\hline
\end{tabular}

Table 6 Thermodynamic functions $\left(\Delta G_{A}^{0}, \Delta S_{A}^{0}, \Delta H_{A}^{0}\right)$ of IL in aqueous d(-)fructose and $\mathrm{d}(+)$ galactose solutions as a function of ionic liquid molality $(\mathrm{m})$ at different temperatures

\begin{tabular}{llll}
\hline $\mathrm{T}(\mathrm{K})$ & $\Delta G_{A}^{0}\left(\mathrm{~kJ} \mathrm{~mol}^{-1}\right)$ & $\Delta S_{A}^{0}\left(\mathrm{~J} \mathrm{~mol}^{-1} \mathrm{~K}^{-1}\right)$ & $\Delta H_{A}^{0}\left(\mathrm{~kJ} \mathrm{~mol}^{-1}\right)$ \\
\hline $\mathrm{m}_{\mathrm{D}(-) \text { fructose }}=0.2 \mathrm{~mol} \mathrm{~kg}^{-1}$ & & \\
\hline 298.15 & -9.59 & 263.30 & 68.91 \\
303.15 & -10.55 & 131.65 & 29.36 \\
308.15 & -10.58 & 11.31 & -7.09 \\
\hline $\mathrm{m}_{\mathrm{D}(-) \text { fructose}=0.4 \mathrm{~mol} \mathrm{~kg}^{-1}}$ & & \\
\hline 298.15 & -9.76 & 253.90 & 65.76 \\
303.15 & -10.70 & 126.95 & 27.78 \\
308.15 & -10.75 & 10.91 & -7.39 \\
\hline $\mathrm{m}_{\mathrm{D}(-) \text { fructose }=0.6 \mathrm{~mol} \mathrm{~kg}^{-1}}$ & \\
\hline 298.15 & -9.92 & 232.33 & 59.35 \\
303.15 & -10.82 & 116.15 & 24.39 \\
308.15 & -10.90 & 9.97 & -7.83 \\
\hline $\mathrm{m}_{\mathrm{D}(+) \text { galactose }}=0.2 \mathrm{~mol} \mathrm{~kg}^{-1}$ & & \\
\hline 298.15 & -9.92 & 238.80 & 25.28 \\
303.15 & -10.64 & 119.40 & -7.51 \\
\hline 308.15 & -10.68 & 10.28 & \\
\hline $\mathrm{m}_{\mathrm{D}(+) \text { galactose }}=0.4 \mathrm{~mol} \mathrm{~kg}^{-1}$ & &
\end{tabular}

https://doi.org/10.30799/jacs.173.18040103

Cite this Article as: Biswajit Datta, Ananya Yasmin, Mahendra Nath Roy, Study to explore diverse interactions by physicochemical contrivance of an ionic liquid in aqueous oligosaccharides J. Adv. Chem. Sci. 4(1) (2018) 534-542.

\begin{tabular}{llll}
\hline 298.15 & -10.01 & 197.50 & 48.87 \\
303.15 & -10.76 & 98.75 & 19.18 \\
308.15 & -10.81 & 8.49 & -8.19 \\
\hline $\mathrm{m}_{\mathrm{D}(+) \text { galactose }}=0.6 \mathrm{~mol} \mathrm{~kg}-1$ & & \\
\hline 298.15 & -10.14 & 188.50 & 46.06 \\
303.15 & -10.89 & 94.25 & 17.68 \\
308.15 & -10.92 & 8.09 & -8.43 \\
\hline
\end{tabular}

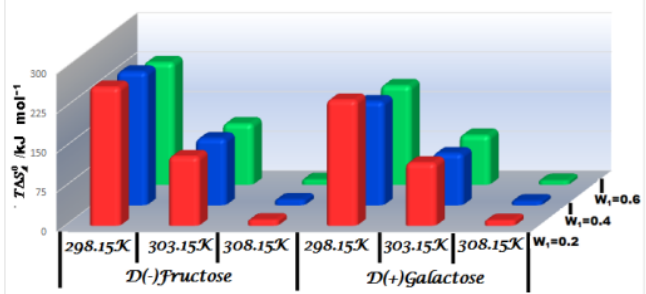

Fig. 1 Plot of $T \Delta S_{A}^{0}$ of IL in different mass fractions of aqueous D(-)fructose and $\mathrm{D}(+)$ galactose solution respectively at different temperatures

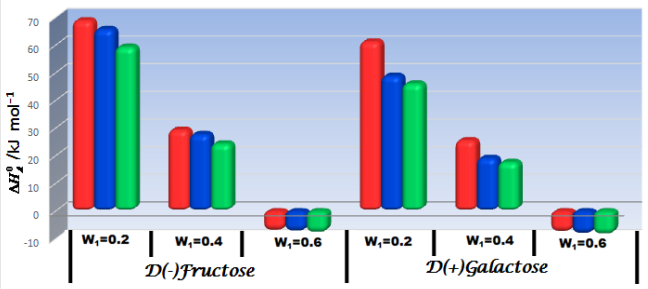

Fig. 2 Plot of $\Delta H_{A}^{0}$ of IL in different mass fractions of aqueous $\mathrm{D}(-)$ fructose and $\mathrm{D}(+)$ galactose solution respectively at $298.15 \mathrm{~K}$ (red), $303.15 \mathrm{~K}$ (blue) and $308.15 \mathrm{~K}$ (green) respectively

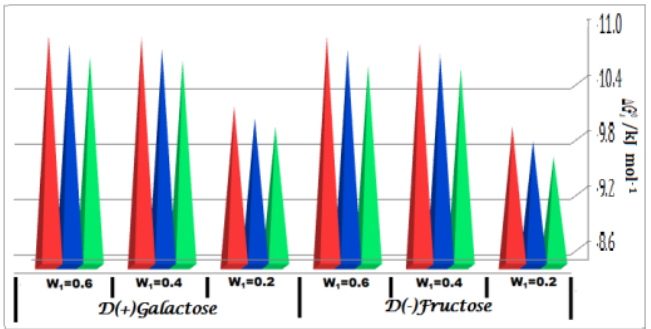

Fig. 3 Plot of $\Delta G_{A}^{0}$ of IL in different mass fraction of aqueous $\mathrm{D}(-)$ fructose and $\mathrm{D}(+)$ galactose solution respectively at $298.15 \mathrm{~K}$ (red), $303.15 \mathrm{~K}$ (blue) and $308.15 \mathrm{~K}$ (green) respectively

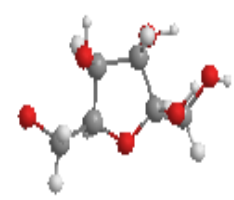

$\mathrm{D}(-)$ fructose

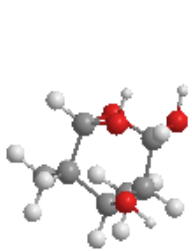

$\mathrm{D}(+)$ galactose

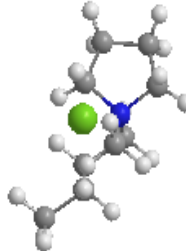

IL

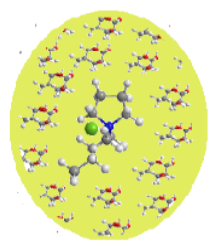

$\mathrm{IL}+$ aq. $\mathrm{D}(+)$ galactose

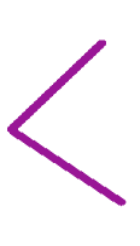

Scheme 1 Molecular structure of D(-)fructose, D(+)galactose, IL and Extent of ionsolvent interaction of ionic liquid in diverse solution systems

The positive contribution of entropy resulting from the dehydration of ions during the association process dominants over the negative contribution from the formation ion -pairs. It should be noted that the entropy term $\left(\mathrm{T} \Delta \mathrm{S}_{\mathrm{A}}{ }^{0}\right)$ is sufficiently positive to exceed the positive contribution of the enthalpy $\left(\Delta \mathrm{H}_{\mathrm{A}}{ }^{0}\right)$. Consequently, the ion-association process exhibits negative values of $\Delta \mathrm{G}_{\mathrm{A}}{ }^{0}$ and the process is driven by the change in entropy. Assessment of Table 6 also indicates that in case of [bmp]Cl in both aqueous solution of $\mathrm{D}(-)$ fructose than in $\mathrm{D}(+)$ galactose 
enthalpy decreases with increasing temperature and changes its sign from positive to negative at $308.15 \mathrm{~K}$. This means that the association process is endothermic at lower temperature and exothermic at higher temperature. Furthermore, it means that ion-pair formation is entropydriven at low temperatures, while it changes to enthalpy-driven process with increasing temperature. Enthalpy value of the IL is higher in case of $\mathrm{D}(-)$ fructose than in $\mathrm{D}(+)$ galactose. This means that the association process is more feasible in $\mathrm{D}(+)$ galactose than in $\mathrm{D}(-)$ fructose (Scheme 1). It was observed that the ion-association process exhibits a negative value of $\Delta \mathrm{G}_{\mathrm{A}}{ }^{0}$ and becomes more negative with increasing temperature proposing the spontaneity and feasibility of the association at high temperatures. It is also an attempt to explore the consequence of interaction of carbohydrates with ionic liquids, consequently, by means of the interaction between IL and biomolecules, the potential toxicity of ILs may originate.

\subsection{Apparent Molar Volume}

From density measurement it is known that the densities of the IL in each aqueous $\mathrm{D}(-)$ fructose and $\mathrm{D}(+)$ galactose increase linearly with the concentration at the studied temperatures. The density values of IL are higher in aqueous $\mathrm{D}(-)$ fructose solution than in aqueous $\mathrm{D}(+)$ galactose solution. For this purpose, the apparent molar volumes $\phi_{V}$ were determined from the solution densities using the following equation

$$
\phi_{V}=M / \rho-\left(\rho-\rho_{o}\right) / m \rho_{o} \rho
$$

Where $M$ is the molar mass of the solute, $m$ is the molality of the solution, $\rho$ and $\rho_{0}$ are the densities of the solution and solvent, respectively.

The limiting apparent molar volumes $\phi_{V}^{0}$ were calculated using a leastsquares treatment to the plots of $\phi_{V}$ versus $\sqrt{m}$ using the following Masson equation [19].

$$
\phi_{V}=\phi_{V}^{0}+S_{V}^{*} \cdot \sqrt{ } m
$$

Where, $\phi_{V}^{0}$ is the limiting apparent molar volume at infinite dilution and $S_{V}^{*}$ is the experimental slope.

The limiting apparent molar volumes $\phi_{V}^{0}$ are found to increase with increasing molality $(m)$ of IL in each solvents and decrease with increasing temperature for the studied system.

Table 7 Limiting apparent molar volume $\left(\phi_{\mathrm{V}}^{0}\right)$, experimental slope $\left(\mathrm{S}_{\mathrm{V}}^{*}\right)$, viscosity-B and $\mathrm{A}$ co-efficients of IL in aqueous $\mathrm{d}(-)$ fructose and $\mathrm{d}(+)$ galactose

\begin{tabular}{|c|c|c|c|c|}
\hline $\mathrm{T}(\mathrm{K})$ & $\begin{array}{c}\phi_{\mathrm{V}}^{0} \cdot 10^{6} / \\
\mathrm{m}^{3} \cdot \mathrm{mol}^{-1}\end{array}$ & $\begin{array}{l}\mathrm{S}_{\mathrm{V}}^{*} \cdot 10^{6} / \\
\mathrm{m}^{3} \cdot \mathrm{mol}^{-3 / 2} \\
\cdot \mathrm{dm}^{3 / 2}\end{array}$ & $B / \mathrm{dm}^{3} \cdot \mathrm{mol}^{-1}$ & $A / \mathrm{dm}^{3 / 2} \cdot \mathrm{mol}^{-1 / 2}$ \\
\hline \multicolumn{5}{|c|}{$\mathrm{m}_{\mathrm{D}(\mathrm{-}) \text { fructose }}=0.2 \mathrm{~mol} \mathrm{~kg}^{-1}$} \\
\hline 298.15 & 120.56 & -242.28 & 0.959 & -0.0749 \\
\hline 303.15 & 129.31 & -259.39 & 1.108 & -0.0780 \\
\hline 308.15 & 140.91 & -337.66 & 1.213 & -0.0851 \\
\hline \multicolumn{5}{|c|}{$\mathrm{m}_{\mathrm{D}(\mathrm{-}) \text { fructose }}=0.4 \mathrm{~mol} \mathrm{~kg}^{-1}$} \\
\hline 298.15 & 124.73 & -237.81 & 1.159 & $\begin{array}{l}-0.0779 \\
\end{array}$ \\
\hline 303.15 & 133.62 & -249.15 & 1.301 & -0.0868 \\
\hline 308.15 & 149.67 & -329.07 & 1.376 & -0.0951 \\
\hline \multicolumn{5}{|c|}{$\mathrm{mD}_{\mathrm{D}(-) \text { fructose }}=0.6 \mathrm{~mol} \mathrm{~kg}^{-1}$} \\
\hline 298.15 & 129.03 & -233.04 & 1.457 & -0.0959 \\
\hline 303.15 & 138.12 & -246.93 & 1.529 & -0.0967 \\
\hline 308.15 & 155.35 & -321.23 & 1.662 & -0.0979 \\
\hline \multicolumn{5}{|c|}{$\mathrm{m}_{\mathrm{D}(+) \text { )galactose }}=0.2 \mathrm{~mol} \mathrm{~kg}^{-1}$} \\
\hline 298.15 & 114.05 & -256.05 & 0.907 & -0.0602 \\
\hline 303.15 & 125.35 & -269.07 & 1.088 & -0.0685 \\
\hline 308.15 & 134.08 & -338.68 & 1.185 & -0.0712 \\
\hline \multicolumn{5}{|c|}{$\mathrm{m}_{\mathrm{D}(+) \text { galactose }}=0.4 \mathrm{~mol} \mathrm{~kg}^{-1}$} \\
\hline 298.15 & 121.38 & -240.15 & 1.136 & -0.0670 \\
\hline 303.15 & 130.77 & -257.67 & 1.273 & -0.0794 \\
\hline 308.15 & 144.43 & -336.45 & 1.313 & -0.0856 \\
\hline \multicolumn{5}{|c|}{$\mathrm{m}_{\mathrm{D}(+) \text { galactose }}=0.6 \mathrm{~mol} \mathrm{~kg}^{-1}$} \\
\hline 298.15 & 126.29 & -235.65 & 1.316 & -0.0747 \\
\hline 303.15 & 135.72 & -248.21 & 1.356 & -0.0790 \\
\hline 308.15 & 152.16 & -324.43 & 1.462 & -0.0841 \\
\hline
\end{tabular}
solutions at different temperatures

From Table 7 it is observed that $\phi_{V}^{0}$ values are positive in both the solution systems and is higher in case of $\mathrm{D}(-)$ fructose compared to $\mathrm{D}(+)$ galactose. This indicates the presence of strong ion-solvent https://doi.org/10.30799/jacs.173.18040103 interactions and the extent of interactions increases in D(-)fructose than in $\mathrm{D}(+)$ galactose solution (Fig. 4). On the contrary, the $S_{V}{ }^{*}$ indicates the extent of ion-ion interaction. The values of $S_{V}{ }^{*}$ shows that the extent of ionion interaction is higher in case of $\mathrm{D}(+)$ galactose than $\mathrm{D}(-)$ fructose. Owing to a quantitative comparison, the magnitude of $\phi_{v}^{0}$ are much greater than $S v^{*}$, in every solutions, suggests that ion-solvent interactions dominate over ion-ion interactions in all the solutions. The values of $\phi_{V}^{0}$ also support the fact that higher ion-solvent interaction of IL leads to lower conductance in $\mathrm{D}(-)$ fructose than $\mathrm{D}(+)$ galactose, discussed earlier [20-22].

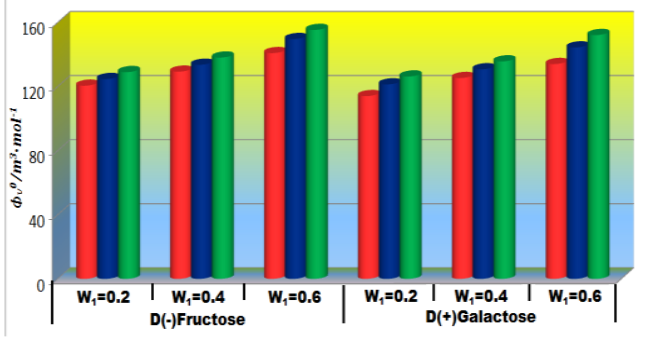

Fig. 4 Plot of limiting molar volume $\left(\phi_{V}^{0}\right)$ of IL against mass fraction $(w)$ of aqueous $\mathrm{D}(-)$ fructose and $\mathrm{D}(+)$ galactose at $298.15 \mathrm{~K}$ (red), $303.15 \mathrm{~K}$ (blue) and $308.15 \mathrm{~K}$ (green) respectively

The transfer volumes, $\Delta_{t r} \phi_{V}^{0}$ of $\mathrm{D}(-)$ fructose and $\mathrm{D}(+)$ galactose from water to aqueous [bmpy]Cl solutions have been calculated as follows [23]

$$
\Delta_{t r} \phi_{V}^{0}=\phi_{V}^{0}(\text { in }[\text { bmp }] C l+\text { aq.carbohydrate })-\phi_{V}^{0}(a q .)
$$

where $\phi_{V}^{0}($ in $[$ bmp $] C l+$ aq.carbohydrate $)$ and $\phi_{V}^{0}(a q$.$) are the standard$ partial molar volumes of [bmpy] $\mathrm{Cl}$ in aqueous carbohydrates [D(-) fructose and $\mathrm{D}(+)$ galactose] and in water, respectively. The obtained values for the transfer volumes are given in Table 8. Here we have determined the standard partial molar volume of aqueous carbohydrates [24-26]. Perusal of Table 8 shows, the values of $\Delta_{t r} \phi_{v}^{0}$ values are positive and increase with increase in the concentration of ionic liquid at each experimental temperatures. The following types of interactions are possible between solute $[\mathrm{D}(-)$ fructose and $\mathrm{D}(+)$ galactose $]$ and co-solute (ionic liquid) in ternary solutions being studied: (i) Hydrophilic-ionic interactions between the hydrophilic sites $(-\mathrm{OH},-\mathrm{C}=0$, and $-\mathrm{O}-)$ of $[\mathrm{D}(-)$ fructose and $\mathrm{D}(+)$ galactose $]$ and the ions $\left([\mathrm{bmp}]^{+} / \mathrm{Cl}^{-}\right)$of ionic liquid; (ii) Hydrophobic-ionic interactions between the hydrophobic parts of $[\mathrm{D}(-)$ fructose and $\mathrm{D}(+)$ galactose] and the ions of ionic liquid. According to the co-sphere overlap model [27], type (i) interactions contribute positively, whereas the type (ii) interactions make negative contributions to $A_{r} \phi_{V}^{0}$ values. The positive ${ }_{A_{r}} \phi_{V}^{0}$ values obtained for D(-) fructose and $\mathrm{D}(+)$ galactose in the studied solutions suggest that the hydrophilic-ionic interactions predominate over the hydrophobic-ionic interactions.

\begin{tabular}{|c|c|c|c|c|}
\hline $\begin{array}{l}\text { Temp } \\
/ \mathrm{K}\end{array}$ & $\begin{array}{l}\phi_{\mathrm{v}}^{0} \cdot 10^{6}(\mathrm{aq}) \\
/ \mathrm{m}^{3} \cdot \mathrm{mol}^{-1}\end{array}$ & $\begin{array}{l}\Delta \phi_{\mathrm{V}_{\mathrm{tr}}^{0}}^{0} \cdot 10^{6} \\
/ \mathrm{m}^{3} \cdot \mathrm{mol}^{-1}\end{array}$ & $\begin{array}{l}B(\mathrm{aq}) \\
/ \mathrm{kg} \cdot \mathrm{mol}^{-1}\end{array}$ & $\begin{array}{l}\Delta B \\
/ \mathrm{kg} \cdot \mathrm{mol}^{-1}\end{array}$ \\
\hline \multicolumn{5}{|c|}{$\mathrm{mD}_{\mathrm{D}-\mathrm{f} \text { fructose }}=0.2 \mathrm{~mol} \mathrm{~kg}^{-1}$} \\
\hline 298.15 & 112.01 & 8.55 & 0.890 & 0.069 \\
\hline 303.15 & 112.23 & 17.08 & 1.033 & 0.075 \\
\hline 308.15 & 112.71 & 28.20 & 1.129 & 0.084 \\
\hline \multicolumn{5}{|c|}{$\mathrm{m}_{\mathrm{D}(-) \text { fructose }}=0.4 \mathrm{~mol} \mathrm{~kg}^{-1}$} \\
\hline 298.15 & 112.95 & 11.78 & 1.085 & 0.074 \\
\hline 303.15 & 113.03 & 20.59 & 1.22 & 0.081 \\
\hline 308.15 & 113.11 & 36.56 & 1.283 & 0.093 \\
\hline \multicolumn{5}{|c|}{$\mathrm{mD}_{\mathrm{D}-\mathrm{f} \text { fructose }}=0.6 \mathrm{~mol} \mathrm{~kg}^{-1}$} \\
\hline 298.15 & 113.21 & 15.82 & 1.377 & 0.080 \\
\hline 303.15 & 113.27 & 24.85 & 1.44 & 0.089 \\
\hline 308.15 & 113.35 & 42.00 & 1.563 & 0.099 \\
\hline \multicolumn{5}{|c|}{$\mathrm{m}_{\mathrm{D}(+) \text { galactose }}=0.2 \mathrm{~mol} \mathrm{~kg}^{-1}$} \\
\hline 298.15 & 112.01 & 2.04 & 0.842 & 0.065 \\
\hline 303.15 & 112.23 & 13.12 & 1.016 & 0.072 \\
\hline
\end{tabular}

Table 8 Values of $\phi_{\mathrm{V}}^{0}(\mathrm{aq}), \Delta \phi_{\mathrm{V} \text { tr }}^{0}, B$ (aqueous), $\Delta B$ for IL in different solvent systems at different temperatures 


\begin{tabular}{lllll}
\hline 308.15 & 112.71 & 21.37 & 1.102 & 0.083 \\
\hline \multicolumn{2}{l}{$\mathrm{m}_{\mathrm{D}(+) \text { galactose }}=0.4 \mathrm{~mol} \mathrm{~kg}^{-1}$} & & & \\
\hline 298.15 & 112.95 & 8.43 & 1.065 & 0.071 \\
303.15 & 113.03 & 17.74 & 1.197 & 0.076 \\
308.15 & 113.11 & 31.32 & 1.234 & 0.079 \\
\hline \multicolumn{2}{l}{$\mathrm{m}_{\mathrm{D}(+) \text { galactose }}=0.6 \mathrm{~mol} \mathrm{~kg}^{-1}$} & & & \\
\hline 298.15 & 113.21 & 13.08 & 1.242 & 0.074 \\
303.15 & 113.27 & 22.45 & 1.275 & 0.081 \\
308.15 & 113.35 & 38.81 & 1.369 & 0.093 \\
\hline
\end{tabular}

Therefore, more the number of interacting centres (-OH group) present in the carbohydrate, more is its interaction with the IL. A possible interaction between the plausible products (obtained with reaction between different carbohydrates and IL) with water is given in Scheme 2.

Interaction pattern between $\mathrm{D}(-)$ fructose, $\mathrm{D}(+)$ galactose and IL can be summarized such as [23]:

a. The interactions between the $-\mathrm{OH}$ group of the saccharides and the ionic part of IL named as hydrophilic-ionic group interactions.

b. The interactions occurring between the $-\mathrm{OH}$ group of the saccharides and $\mathrm{N}$-atom of pyrrolidinium group present in IL termed as hydrophilichydrophilic interactions.

Table 9 Values of empirical coefficients $\left(a_{0}, a_{1}\right.$, and $a_{2}$ ) of eqn (17) for IL in different solvent systems

\begin{tabular}{llll}
\hline Conc. $(\mathrm{m})$ & $a_{0.10^{-6}\left(\mathrm{~J} \mathrm{~mol}^{-1}\right)}$ & $a_{1}\left(\mathrm{KJ} \mathrm{mol}^{-1} \mathrm{~K}^{-1}\right)$ & $a_{2}\left(\mathrm{~J} \mathrm{~mol}^{-1} \mathrm{~K}^{-2}\right)$ \\
\hline $\mathrm{D}(-)$ fructose & & & \\
\hline 0.2 & 0.0085 & -0.0569 & 0.0097 \\
0.4 & 0.0125 & -0.0843 & 0.1432 \\
0.6 & 0.0143 & -0.0967 & 0.1628 \\
\hline $\mathrm{D}(+)$ galactose & & & \\
\hline 0.2 & -0.0052 & 0.0332 & -0.0510 \\
0.4 & 0.0153 & -0.1027 & 0.1734 \\
0.6 & 0.0195 & -0.1309 & 0.2202 \\
\hline
\end{tabular}

Table 10 Limiting apparent molal expansibilities $\left(\phi_{E}^{0}\right)$ and $\left(\delta \varphi_{E}^{0} / \delta T\right)_{P}$ for IL in different solvent systems at different temperatures

\begin{tabular}{lll}
\hline $\mathrm{T}(\mathrm{K})$ & $\phi_{E}^{0}$ & $\left(\delta \varphi_{E}^{0} / \delta T\right)_{P}$ \\
\hline $\mathrm{m}_{\mathrm{D}(-) \text { fructose }=0.2 \mathrm{~mol} \mathrm{~kg}^{-1}}$ & \\
\hline 298.15 & 57.78 & 0.194 \\
303.15 & 58.75 & 0.194 \\
308.15 & 59.72 & 0.194 \\
\hline $\mathrm{m}_{\mathrm{D}(-) \text { fructose }=0.4 \mathrm{~mol} \mathrm{~kg}^{-1}}$ & \\
\hline 298.15 & 85.30 & 0.286 \\
303.15 & 86.61 & 0.286 \\
308.15 & 88.04 & 0.286 \\
\hline $\mathrm{m}_{\mathrm{D}(-) \text { fructose }=0.6 \mathrm{~mol} \mathrm{~kg}^{-1}}$ & \\
\hline 298.15 & 100.20 & 0.336 \\
303.15 & 101.76 & 0.336 \\
308.15 & 103.44 & 0.336 \\
\hline $\mathrm{m}_{\mathrm{D}(+) \text { galactose }}=0.2 \mathrm{~mol} \mathrm{~kg}^{-1}$ & \\
298.15 & -29.84 & -0.100 \\
303.15 & -30.04 & -0.100 \\
308.15 & -30.84 & -0.100 \\
\hline $\mathrm{m}_{\mathrm{D}(+) \text { galactose }}=0.4 \mathrm{~mol} \mathrm{~kg}^{-1}$ & \\
\hline 298.15 & 103.29 & 0.347 \\
303.15 & 105.02 & 0.347 \\
308.15 & 106.76 & 0.347 \\
\hline $\mathrm{m}_{\mathrm{D}(+) \text { galactose }}=0.6 \mathrm{~mol} \mathrm{~kg}^{-1}$ & \\
\hline 298.15 & 129.99 & 0.440 \\
303.15 & 133.37 & 0.440 \\
308.15 & 135.57 &
\end{tabular}

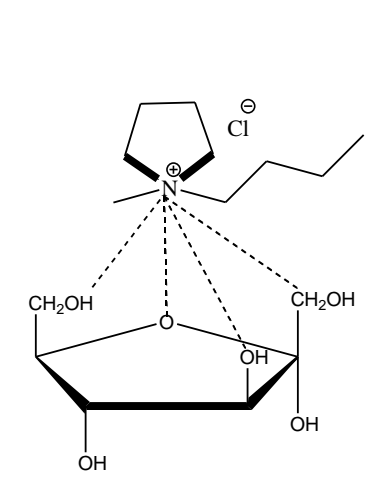

Interaction between $\mathrm{D}(-)$ fructose and $\mathrm{IL}\left(\mathrm{I}_{1}\right) \quad$ Interaction between $\mathrm{D}(+)$ galactose and IL $\left(\mathrm{I}_{2}\right)\left(\mathrm{I}_{1}>\mathrm{I}_{2}\right)$

Scheme 1 Plausible Interfaces between ionic liquid and diverse solvent systems

Thus the interactions between IL and carbohydrate in water solutions can generally be summarized as, (a) the hydrogen bonding interaction between the $\mathrm{H}$ atoms of water with (i) $-\mathrm{O}$ atom of the $-\mathrm{OH}$ group attached to the carbohydrate and (ii) $-\mathrm{N}$ atom in the heterocyclic ring of IL; (b) the hydrogen bonding interaction between the $\mathrm{O}$ atom of water with the $\mathrm{H}$ atom associated with the $-\mathrm{OH}$ group attached to the carbohydrate. c. The interactions present here in between the $-\mathrm{OH}$ group of the saccharides and the non-polar part of the IL can be said as hydrophilichydrophobic interactions.

The overall positive values of $\phi_{V}^{0}$ (Table 7) for the systems reinforce the fact that the solute-solvent interactions are predominate. Therefore the mutual overlap of the hydration spheres of solute and cosolute molecules will lead to an increase in the magnitude of hydrogen bonding interactions between the plausible products (obtained with reaction between IL and different carbohydrates) with water. The observation shows that with increase in the number of the interacting centers (-OH groups) present in the studied carbohydrates, the solutesolvent interaction also increases [28-30]. The solute-solvent interaction in case of $\mathrm{D}(-)$ fructose is greater than $\mathrm{D}(+)$ galactose because of the presence of greater number of free $-\mathrm{OH}$ group in $\mathrm{D}(-)$ fructose. Also $\mathrm{D}(+)$ galactose is six-membered ring so there is some sort of structural restriction, whereas $\mathrm{D}(-)$ fructose is five-membered ring which containing more free $-\mathrm{OH}$ group favored $\mathrm{H}$-bonding to a greater extent. Therefore, the solute-solvent interaction is superior in $\mathrm{D}(-)$ fructose compared to $\mathrm{D}(+)$ galactose solution.

\subsection{Temperature Dependent Limiting Apparent Molar Volume}

The temperature dependent general polynomial equation for $\phi_{V}^{0}$ are as follows [31]

(17)

$$
\phi_{V}^{0}=a_{0}+a_{1} T+a_{2} T^{2}
$$

where, $a_{0}, a_{1}, a_{2}$ are the empirical and $\mathrm{T}$ is the Kelvin temperature. The values of these coefficients are presented in Table 9.

The limiting apparent molar expansibilities, $\phi_{E}^{0}$, can be obtained by the following equation,

$$
\phi_{E}^{o}=\left(\delta \phi_{V}^{0} / \delta T\right)_{P}=a_{1}+2 a_{2} T
$$

where, $\phi_{E}^{0}$ is the change in magnitude with the change of temperature at constant pressure. The values of $\phi_{E}^{0}$ for different solutions of the studied ILs at different Kelvin are reported in Table 10. The table reveals that $\phi_{E}^{0}$ is positive for the IL in the studied solvent systems and studied temperatures. This fact can be ascribed to the absence of caging or packing effect for the IL in solutions.

Hepler [32] developed a technique of examining the sign of $\left(\delta \phi_{E}^{0} / \delta T\right)_{P}$ for the solute in terms of long-range structure-making and breaking capacity of the solute in the mixed solvent systems using the general thermodynamic expression,

$$
\left(\delta \phi_{E}^{0} / \delta T\right)_{P}=\left(\delta^{2} \phi_{V}^{0} / \delta T^{2}\right)_{P}=2 a_{2}
$$

If the sign of $\left(\delta \phi_{E}^{0} / \delta T\right)_{P}$ becomes positive or a small negative, the molecule is a structure maker; otherwise, it is a structure breaker [33]. From Table 10 the $\left(\delta \phi_{E}^{0} / \delta T\right)_{P}$ values for the studied IL in both the solution of $\mathrm{D}(-)$ fructose and $\mathrm{D}(+)$ galactose are positive [in $0.2(\mathrm{~m}) \mathrm{D}$ galactose solution small negative] imply predominantly that the IL is structure maker in all of the experimental solutions for D(-)fructose and $\mathrm{D}(+)$ galactose in aqueous ionic liquid solutions rather than water. This indicates that these saccharides behave as a structure breaker in aqueous system, on the other hand, the structure-breaking tendency decreases due to existence of ionic liquid It can be mentioned here that in generally an enhancement in the solute-solvent interactions is convoyed by a decrease in the solute-cosolute interactions. Since with increasing temperatures, some slackly leaped carbohydrate molecules are released from the secondary solvation shells of the ions, so the solute-solvent interactions can become stronger with the increase of temperature [34]. 


\subsection{Viscosity Calculation}

The viscosity data have been analysed using Jones-Dole equation [35], $\quad\left(\eta / \eta_{0}-1\right) / \sqrt{ } c=A+B \sqrt{ } m$

where, $\eta$ and $\eta_{0}$ are the viscosities of the solution and solvent respectively. The viscosity co-efficient $A$ - and $B$ - represent ion-ion and ion-solvent interaction respectively. Perusal of Table 7 shows that the positive values of $B$-coefficients indicate greater ion-solvent interactions and small negative values of $A$ - coefficients indicate smaller ion-ion interaction in solution. Thereby suggesting the ion-solvent interactions are dominant over the ion-ion interactions. The $B$-coefficient [36] value obtained from the viscosity measurements gives the important information regarding the extent of solvation of the solute molecules and the effects on the structure of the solvents in the local vicinity of the solute molecule in solution. The higher $B$-coefficient values are due to the solvated solutes molecule associated by the solvent molecules by solute-solvent interactions. These types of interactions are strengthened with rise in temperature and thus the values of $B$-coefficient increases with increase in temperature. As a consequence, the inclination of ion-solvent interaction is higher in case of $\mathrm{D}(-)$ fructose solution than in $\mathrm{D}(+)$ galactose solution (Fig. 5). These results are in good agreement with those obtained from $\phi_{V}^{0}$ and $S_{V}^{*}$ values, discussed earlier.

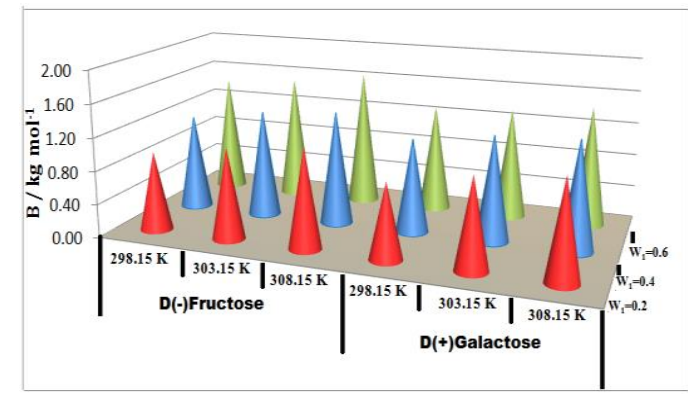

Fig. 5 Plot of viscosity $B$-coefficient of IL against mass fraction $(w)$ of aqueous $\mathrm{D}(-)$ fructose and $\mathrm{D}(+)$ galactose at different temperatures

Viscosity $B$-coefficients of transfer $(\Delta B)$ from water to different aqueous carbohydrate solutions have been determined using the relations [37, 38]

$$
\Delta B(I L)=B(I L+\text { aq.carbohydrate })-B(\text { aq. })
$$

From Table 8 it is evident that $\Delta B$ values are positive and increases with a rise in temperature and with increasing concentration of carbohydrate, thereby suggesting the presence of strong solute-solvent interactions, and the interactions are strengthened with rise in temperature and increase of carbohydrate in aqueous mixture [39]. The observation supports the same results obtained from $\Delta_{r} \phi_{V}^{0}$ values discussed above.

The sign of $d B / d T$ is another tool of structure-forming or -breaking ability of the solute [32]. It is found from Table 11 that the values of the $B$ coefficient increase with a rise in temperature (positive $d B / d T$ values), suggesting the structure breaking tendency [27] of carbohydrates in the solution systems. Moreover, it is interesting to note that the $B$-coefficients of the studied carbohydrates show a linear relationship with the partial molar volumes $\phi_{V}^{0}$, i.e;

$$
\mathrm{B}=\mathrm{A}_{1}+\mathrm{A}_{2} \phi_{V}^{0}
$$

The coefficients $A_{1}$ and $A_{2}$ are included in Table 11. The positive slope (or $A_{2}$ ) shows the linear variation of $B$-coefficient with partial molar volumes $\phi_{V}^{0}$. This relationship is really expected, since both the viscosity $B$-coefficient and the partial molar volume reflect the privileged solutesolvent interactions in the solutions.

Table 11 Values of $d B / d T, A_{1}$ and $A_{2}$ coefficient of equation (22) for the IL in different

\begin{tabular}{|c|c|c|c|}
\hline Conc. (m) & $d B / d T$ & $A_{1}$ & $A_{2}$ \\
\hline \multicolumn{4}{|c|}{ IL+aqueous D(-)fructose } \\
\hline 0.2 & 0.0071 & -0.508 & 0.012 \\
\hline 0.4 & 0.0076 & 0.161 & 0.008 \\
\hline 0.6 & 0.0081 & 0.453 & 0.007 \\
\hline \multicolumn{4}{|c|}{ IL+aqueous $\mathrm{D}(+)$ galactose } \\
\hline 0.2 & 0.0068 & -0.480 & 0.014 \\
\hline 0.4 & 0.0074 & 0.271 & 0.007 \\
\hline 0.6 & 0.0077 & 0.586 & 0.005 \\
\hline
\end{tabular}
solvent systems

\section{$3.7^{1}$ H NMR study}

NMR study is one of the most imperative spectroscopic tools for deeply understanding the microscopic information about the ion-solvent interaction of the studied IL in carbohydrate solution systems. In our present work we have considered the interactions of an IL (viz., [bmp]Cl) with $\mathrm{D}(-)$ fructose and $\mathrm{D}(+)$ galactose by ${ }^{1} \mathrm{H}$ NMR study taking 1:1 molar ratio of IL and $\mathrm{CD}$ in $\mathrm{D}_{2} \mathrm{O}$ at 298.15K [Figs. 6 and 7].
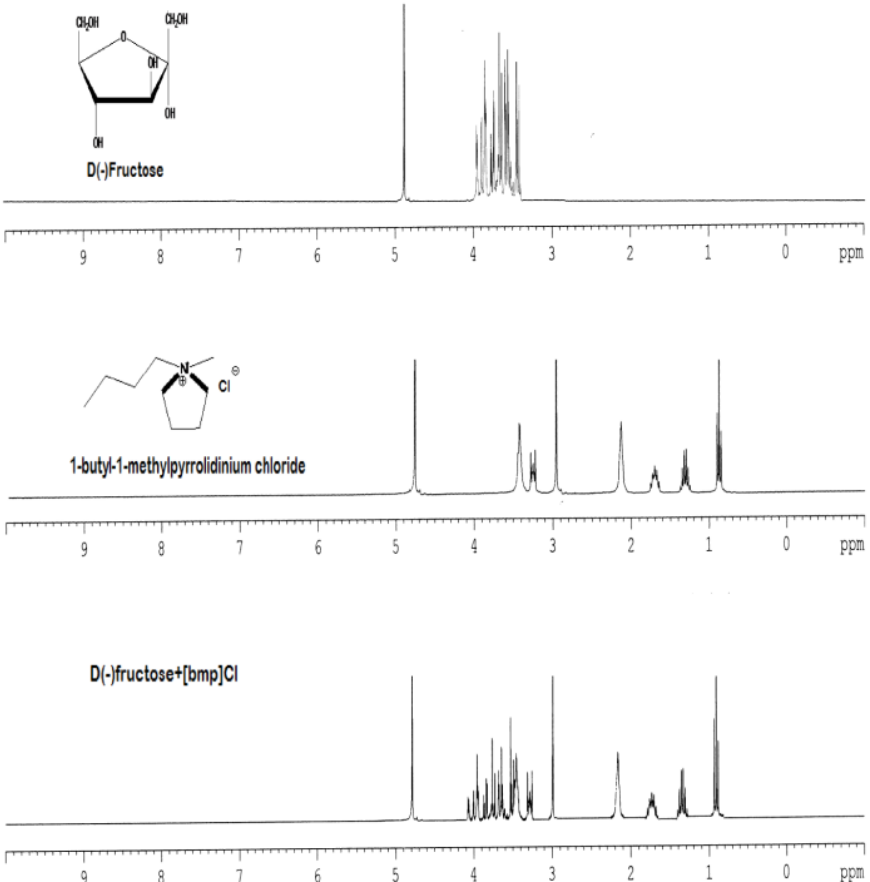

Fig. $6{ }^{1} \mathrm{H}$ NMR Spectra of D(-)Fructose, [BMP]Cl and 1:1 molar ratio of D(-)Fructose $+[\mathrm{BMP}] \mathrm{Cl}$ in $\mathrm{D}_{2} \mathrm{O}$ in $298.15 \mathrm{~K}$

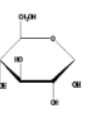

$D(+)$ Galactose

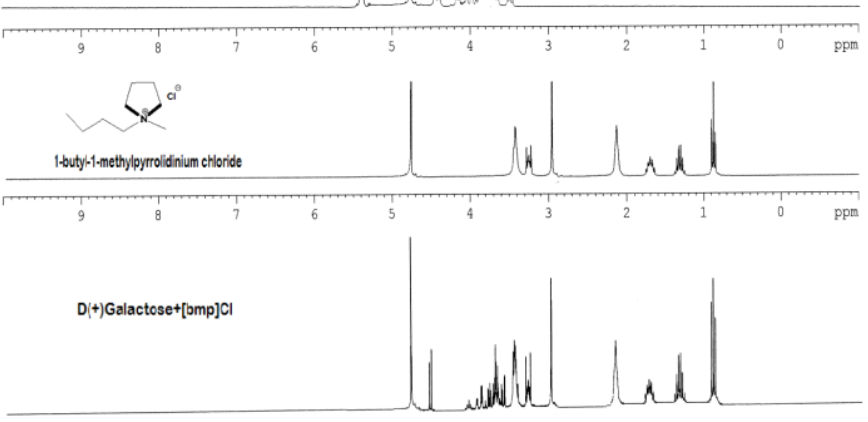

Fig. $7{ }^{1} \mathrm{H}$ NMR Spectra of $\mathrm{D}(+)$ Galactose, $[\mathrm{BMP}] \mathrm{Cl}$ and $1: 1$ molar ratio of $\mathrm{D}(+)$ Galactose $+[\mathrm{BMP}] \mathrm{Cl}$ in $\mathrm{D}_{2} \mathrm{O}$ in $298.15 \mathrm{~K}$

${ }^{1} \mathrm{H}$ NMR data of the IL, two carbohydrates and mixture of ILCarbohydrates are listed in Table 12. Due to the analyzed interactions between the IL and the co-solvents, measurements of NMR are essential for the investigation of the solution state of ionic liquid in carbohydrates. In case of ${ }^{1} \mathrm{H}$ spectra of carbohydrates are often not first order, in which case line separations do not symbolize coupling constants. The protons of the IL show considerable chemical shift due to the interaction with the hydrophilic $-\mathrm{OH}$ groups present in the carbohydrate molecules. In the structure of D(-) Fructose the H1-H6 i.e. all the H-atoms situated in the moiety show the peak in NMR study. Similarly in case of $D(+)$ Galactose the H1-H6 i.e. all the H-atoms situated in the carbohydrate moiety show the peak in NMR study. In case of IL the protons present in butyl as well as methyl group show NMR spectra. The chemical shifts for H-atoms of IL evidently show highfield in presence carbohydrates [40]. It can be inferred that the interactions between the IL and cabohydrates would be mainly resolute by their dehydrations/hydrations in the processes. The change of chemical shift may be due to the disruption of the interionic hydrogen bonding network in ILs [41]. In case of mixture compositions, the variations of relative chemical shifts in thus commenced are interpreted in terms of specific and non-specific intermolecular interactions [42]. The results showed that the solvation process of carbohydrates is governed 
mainly by the interactions between the cationic part of the IL and carbohydrate molecules. The shifts of protons of IL are more in case D()fructose than that of $\mathrm{D}(+)$ galactose. This fact indicates that interaction between the IL and $\mathrm{D}(-)$ fructose is higher than that of IL and $\mathrm{D}(+)$ galactose. The NMR study provides a profound insight into other IL + biomolecule mixed systems, especially afforded theoretical foundations and imperative information for studies on the potential toxicity of ILs.

Table $12{ }^{1} \mathrm{H}$ NMR data of [BMP]Cl, D(-)fructose, D(+)galactose and IL- carbohydrates mixture

[BMP]Cl (300MHz, Solv: $\left.\mathrm{D}_{2} \mathrm{O}\right) \delta / \mathrm{ppm}$

0.91-0.96 (3H, t, $J=7.29 \mathrm{~Hz}), 1.34-1.41(2 \mathrm{H}, \mathrm{m}), 1.74-1.81(2 \mathrm{H}, \mathrm{m}), 2.19(4 \mathrm{H}, \mathrm{m})$,

$3.02(3 \mathrm{H}, \mathrm{s}), 3.28-3.34(2 \mathrm{H}, \mathrm{m}), 3.48(4 \mathrm{H}, \mathrm{m})$

\begin{tabular}{|c|c|}
\hline $\mathrm{D}(-)$ fructose $\left(300 \mathrm{MHz}\right.$, Solv: $\left.\mathrm{D}_{2} \mathrm{O}\right)$ & $\mathrm{D}(+)$ galactose $\left(300 \mathrm{MHz}\right.$, Solv: $\left.\mathrm{D}_{2} \mathrm{O}\right)$ \\
\hline$\delta / \mathrm{ppm}$ & $\delta / \mathrm{ppm}$ \\
\hline $\begin{array}{l}\text { 3.49-3.53 (2H, d), 3.64-3.68 (1H, m), } \\
3.69-3.73(1 \mathrm{H}, \mathrm{m}), 3.77-3.84(1 \mathrm{H}, \mathrm{m}) \text {, } \\
3.88-3.95(1 \mathrm{H}, \mathrm{m}), 3.94-4.06(2 \mathrm{H}, \mathrm{d})\end{array}$ & $\begin{array}{l}3.42-3.47(2 \mathrm{H}, \mathrm{d}), 3.58-3.61(1 \mathrm{H}, \mathrm{m}) \\
3.63-3.70(1 \mathrm{H}, \mathrm{m}), 3.72-3.79(1 \mathrm{H}, \mathrm{m}) \\
3.88-3.94(1 \mathrm{H}, \mathrm{m}), 4.53-4.55(1 \mathrm{H}, \mathrm{d})\end{array}$ \\
\hline [BMP]Cl- D(-)fructose & [BMP]Cl- D(+)galactose \\
\hline$\left(1: 1\right.$ molar ratio, $300 \mathrm{MHz}$, Solv: $\left.\mathrm{D}_{2} \mathrm{O}\right)$ & (1:1 molar ratio, $300 \mathrm{MHz}$, Solv: $\mathrm{D}_{2} \mathrm{O}$ ) \\
\hline$\delta / \mathrm{ppm}$ & $\delta / \mathrm{ppm}$ \\
\hline $\begin{array}{l}0.87-0.92(3 \mathrm{H}, \mathrm{t}), 1.28-1.31(2 \mathrm{H}, \mathrm{m}), \\
1.72-1.80(2 \mathrm{H}, \mathrm{m}), 2.11-2.15(4 \mathrm{H}, \mathrm{m}), \\
2.98(3 \mathrm{H}, \mathrm{s}), 3.20-3.31(2 \mathrm{H}, \mathrm{m}), 3.40- \\
3.46(1 \mathrm{H}, \mathrm{m}), 3.45-3.48(2 \mathrm{H}, \mathrm{d}), 3.59- \\
3.65(1 \mathrm{H}, \mathrm{m}), 3.67-3.70(1 \mathrm{H}, \mathrm{m}), 3.71- \\
3.79(1 \mathrm{H}, \mathrm{m}), 3.81-3.90(1 \mathrm{H}, \mathrm{m}), 3.91- \\
4.01(2 \mathrm{H}, \mathrm{d})\end{array}$ & $\begin{array}{l}\text { 0.90-0.95 (3H, t), 1.29-1.39 (2H, m), 1.73- } \\
1.81(2 \mathrm{H}, \mathrm{m}), 2.14-2.18(4 \mathrm{H}, \mathrm{m}), 3.00(3 \mathrm{H}, \\
\mathrm{s}), 3.24-3.32(2 \mathrm{H}, \mathrm{m}), 3.46-3.48(4 \mathrm{H}, \mathrm{m}), \\
3.41-3.45(2 \mathrm{H}, \mathrm{d}), 3.56-3.60(1 \mathrm{H}, \mathrm{m}), \\
3.60-3.67(1 \mathrm{H}, \mathrm{m}), 3.69-3.76(1 \mathrm{H}, \mathrm{m}), \\
3.84-3.92(1 \mathrm{H}, \mathrm{m}), 4.51-4.53(1 \mathrm{H}, \mathrm{d})\end{array}$ \\
\hline
\end{tabular}

\section{Conclusion}

In our present research study, we have focused on the characteristic interfaces of some model biological systems [D(-)fructose and $\mathrm{D}(+)$ galactose], with an IL. The studied physicochemical properties provide us complete explanation for the interfaces of IL with carbohydrates. From the analysis of thermodynamic data, it is revealed that the association process for [bmp]Cl is higher in case of $\mathrm{D}(+)$ galactose than in $\mathrm{D}(-)$ fructose solution and is endothermic and controlled by entropy at all temperatures. Density and viscosity studies interpret limiting apparent molar volume, $\phi_{V}^{0}$ and viscosity $B$-coefficient which describes that ion-solvent interaction is increased with increasing the conc. of $\mathrm{D}(-)$ fructose and $\mathrm{D}(+)$ galactose and decreased with increasing temperature. NMR study analysis reveals that no specific and stronger interactions occur between IL and carbohydrates. However the study confirms that interaction of IL with carbohydrates is higher in $\mathrm{D}(-)$ fructose than that of $\mathrm{D}(+)$ galactose. The study provides a profound insight into the potential toxicity of ILs in mixed systems of IL and biomolecules.

\section{Acknowledgement}

The authors are thankful to the Departmental Special Assistance Scheme under the University Grants Commission, New Delhi (No.540/6/DRS/2007,SAP-1), India, and Department of Chemistry, University of North Bengal, for financial support and instrument facilities in order to continue this research work.

One of the authors, Prof. M.N. Roy is thankful to University Grant Commission, New Delhi, Government of India for being awarded one time grant under Basic Scientific Research via the grant-in-Aid No. F.4-10/2010 (BSR) regarding his active service for augmenting of research facilities to facilitate further research work.

\section{References}

[1] J. L. Anderson, J. Ding, T. Welton, D.W. Armstrong, Characterizing ionic liquids on the basis of multiple solvation interactions, J. Am. Chem. Soc. 124 (2002) 14247-14254.

[2] S. Pandey, Analytical applications of room-temperature ionic liquids: A review of recent efforts, Anal. Chim. Acta. 556 (2006) 38-45.

[3] T. Welton, Room-temperature ionic liquids. Solvents for synthesis and catalysis, Chem. Rev. 99 (1999) 2071-2083.

[4] P. Bonhote, A. P. Dias, N. Papageorgiou, K. Kalyanasundaram, M. Gratzel, Hydrophobic, highly conductive ambient-temperature molten salts, Inorg. Chem. 35 (1996) 1168-1178.

[5] C.D. Tran, S.H.P. Lacerda, Determination of binding constants of cyclodextrins in room-temperature ionic liquids by near-infrared spectrometry, Anal. Chem. 74 (2002) 5337-5341
[6] K. Zhuo, Y. Chen, J. Chen, G. Bai, J. Wang, Interactions of 1-butyl-3methylimidazolium carboxylate ionic liquids with glucose in water: a study of volumetric properties, viscosity, conductivity and NMR, Phys. Chem. Chem. Phys. 13 (2011) 14542-14549.

[7] B. Datta, S. Barman, M.N. Roy, Self-assembly inclusion of ionic liquid into hollow cylinder oligosaccharides, J. Mol. Liq. 214 (2016) 264-269.

[8] A. Bhattacharjee, M.N. Roy, Ion association and solvation behavior of tetraalkylammonium iodides in binary mixtures of dichloromethane $+\mathrm{N}, \mathrm{N}-$ dimethylformamide probed by a conductometric study, Phys. Chem. Chem. Phys. 12 (2010)14534-14542.

[9] D. Ekka, M.N. Roy, Conductance, a contrivance to explore ion association and solvation behavior of an ionic liquid (tetrabutylphosphonium tetrafluoroborate) in acetonitrile, tetrahydrofuran, 1,3-dioxolane, and their binaries, J. Phys. Chem. B 116 (2012) 11687-11694.

[10] L. Yu, Y. Zhu, X.G. Hu, X.H. Pang, M.W. Zhao, Enthalpic interactions of some $\alpha-$ amino acids with 1, 2-ethanediol in aqueous solutions at $298.15 \mathrm{~K}$, Fluid Phase Equilib. 252 (2007) 28-32.

[11] A. Pal, H. Kumar, R. Maan, H.K. Sharma, S. Sharma, Solute-solvent interactions of glycine, l-alanine, and l-valine in aqueous 1-methyl imidazolium chloride ionic liquid solutions in the temperature interval (288.15 to 308.15$) \mathrm{K}$, J. Chem. Thernodyn. 91 (2015) 146-155.

[12] R.M. Fuoss, Conductimetric determination of thermodynamic pairing constants for symmetrical electrolytes, J. Phy. Chem. 77 (1980) 34-38.

13] P. Beronius, Ionic association and ion solvent interactions. The conductance of lithium bromide in acetone-water mixtures at $15-35{ }^{\circ} \mathrm{C}$, Acta Chem. Scand. 31(A) (1977) 869-876.

[14] R. Dewan, M.N. Roy, Physico-chemical studies of sodium tetraphenylborate and tetrabutylammonium tetraphenylborate in pure nitrobenzene and nitromethane and their binaries probed by conductometry, refractometry and FT-IR spectroscopy, J. Chem. Thermodyn. 54 (2012) 28-34.

[15] D.S. Gill, M.S. Chauhan, Preferential solvation of ions in mixed solvents. Part 4.-Preferential solvation of $\mathrm{Cu}^{+}$in acetone + acetonitrile and $\mathrm{N}, \mathrm{N}-$ dimethylacetamide + acetonitrile mixtures using conductance measurements, Z. Phys. 140 (1984) 139-148.

[16] H. Shekaari, Y. Mansoorib, A. Kazempour, Conductance behavior of ionic liquids, 1-alkyl-3-methylimidazolium bromide, in aqueous d-xylose solutions, Electrochim. Acta 67 (2012) 104-108.

[17] J. Barthel, M.B. Rogac, R. Neueder, Conductivity of sodium chloride in water +1 , 4-dioxane mixtures at temperatures from 5 to $35 \mathrm{C}$ I. Dilute solutions, J. Soln. Chem. 28 (1999) 1071-1086.

[18] H. Shekaari, A. Kazempour, Ion association constants of ionic liquids, 1-hexyl3-methylimidazolium halide, in aqueous d-fructose solutions, Electrochim. Acta 80 (2012) 196-201.

[19] D.O. Masson, Solute molecular volumes in relation to solvation and ionization, Phil. Magaz. 8 (1929) 218-235.

[20] B. Datta, M.N. Roy, Essential foundation of triple-ion and ion-pair formation of tetraheptylammonium iodide (Hept4NI) salt in organic solvents investigated by physicochemical approach, Phys. Chem. Liq. 53 (2015) 574-586.

[21] M.N. Roy, T. Ray, M.C. Roy, B. Datta, Study of ion-pair and triple-ion origination of an ionic liquid ([bmmim] [BF4]) predominant in solvent systems, RSC Adv. 4 (2014) 62244-62254.

[22] R. Dewan, B. Datta, M.C. Roy, M.N. Roy, Ionic interplay of lithium salts in binary mixtures of acetonitrile and diethyl carbonate probed by physicochemical approach, Fluid Phase Equilib. 358 (2013) 233-240.

[23] H. Shekaari, A. Kazempour, Z. Ghasedi-Khajeh, Structure-making tendency of ionic liquids in the aqueous d-glucose solutions, Fluid Phase Equilib. 316 (2012) 102-108.

[24] H. Shekaari, A. Kazempour, Effect of ionic liquid, 1-octyl-3-methylimidazolium bromide on the thermophysical properties of aqueous d-glucose solutions at 298.15 K, Fluid Phase Equilib. 309 (2011) 1-7.

[25] P.K. Banipal, T.S. Banipal, J.C. Ahluwalia, B.S. Lark, Partial molar heat capacities and volumes of transfer of some saccharides from water to aqueous sodium chloride solutions at $\mathrm{T}=298.15 \mathrm{~K}$, J. Chem. Thermodyn. 34 (2002) 1825-1846.

[26] H. Kumar, I. Behal, M. Singla, Effect of l-serine and l-threonine on volumetric and acoustic behaviour of aqueous metformin hydrochloride solutions at $\mathrm{T}=(305.15,310.15$ and $315.15 \mathrm{~K})$, J. Chem. Thermodyn. 95 (2016) 1-14.

[27] A. Pal, N. Chauhan, Densities, speeds of sound and viscosities of L-alanine in aqueous fructose, maltose and lactose solutions at different temperatures, Ind. J. Chem. 48(A) (2009) 1069-1077.

[28] R.W. Gurney, Ionic Processes in Solution, McGraw Hill, New York, 1953.

[29] A.K. Covington, T. Dickinson, Physical chemistry of organic solvent systems, Plenum, New York, 1973.

[30] K.B. Belibagli, E. Agranci, Viscosities and apparent molar volumes of some amino acids in water and in $6 \mathrm{M}$ guanidine hydrochloride at $25^{\circ} \mathrm{C}$, J. Solution Chem. 19 (1990) 867-882.

31] M.N. Roy, R. Chanda, R.K. Das, D. Ekka, Densities and viscosities of citric acid in aqueous cetrimonium bromide solutions with reference to the manifestation of solvation, J. Chem. Eng. Data. 56 (2011) 3285-3290.

[32] L.G. Helper, Studies on viscosities and densities of R4NX in ME+ water mixtures of different temperatures, Canad. J. Chem. 47 (1969) 4613-4617.

[33] N. Dey, B.K. Saikia, I. Haque, Viscosities of glycine and DL-alanine in water acetonitrile mixtures between 25 and $40{ }^{\circ} \mathrm{C}$, Canad. J. Chem. 58 (1980) 1512 1515.

[34] H. Shekaari, A. Kazempourb, M. Khoshalhan, Schiff base ligands and their transition metal complexes in the mixtures of ionic liquid + organic solvent: a thermodynamic study, Phys. Chem. Chem. Phys. 17 (2015) 2179-2191.

[35] G. Jones, M. Dole, The viscosity of aqueous solutions of strong electrolytes with special reference to barium chloride, J. Am. Chem. Soc. 51 (1929) 2950-2964.

[36] F.J. Millero, Molal volumes of electrolytes, Chem. Rev. 71 (1971) 147-176. 
[37] I. Banik, M.N. Roy, Study of solute-solvent interaction of some bio-active solutes prevailing in aqueous ascorbic acid solution, J. Mol. Liq. 169 (2012) 814.

[38] A. Ali, S. Hyder, S. Sabir D. Chand, A.K. Nain, Volumetric, viscometric, and refractive index behaviour of $\alpha$-amino acids and their groups' contribution in aqueous d-glucose solution at different temperatures, J. Chem. Thermodyn. 38 (2006) 136-143.

[39] T. Ray, M.N. Roy, Study to explore assorted interfaces of an ionic liquid prevailing in solvent systems by physicochemical approach, RSC Adv. 5 (2015) 89431-89440.

[40] R.C. Remsing, I.D. Petrik, Z. Liuc, G. Moyna, Comment on "NMR spectroscopic studies of cellobiose solvation in EmimAc aimed to understand the dissolution mechanism of cellulose in ionic liquids, Phys. Chem. Chem. Phys. 12 (2010) 14827-14828.

[41] L. Jia, C.M. Pedersen, Y. Qiao, T. Deng, P. Zuo, W. Ge, Z. Qin, X. Hou, Y. Wang Glucosamine condensation catalyzed by 1-ethyl-3-methylimidazolium acetate: mechanistic insight from NMR spectroscopy, Phys. Chem. Chem. Phys. 17 (2015) 23173-23182.

[42] B.A. Marekha, O.N. Kalugin, M. Briac, A. Idrissi, Probing structural patterns of ion association and solvation in mixtures of imidazolium ionic liquids with acetonitrile by means of relative $1 \mathrm{H}$ and $13 \mathrm{C}$ NMR chemical shifts, Phys. Chem. Chem. Phys. 17 (2015) 23183-23194. 